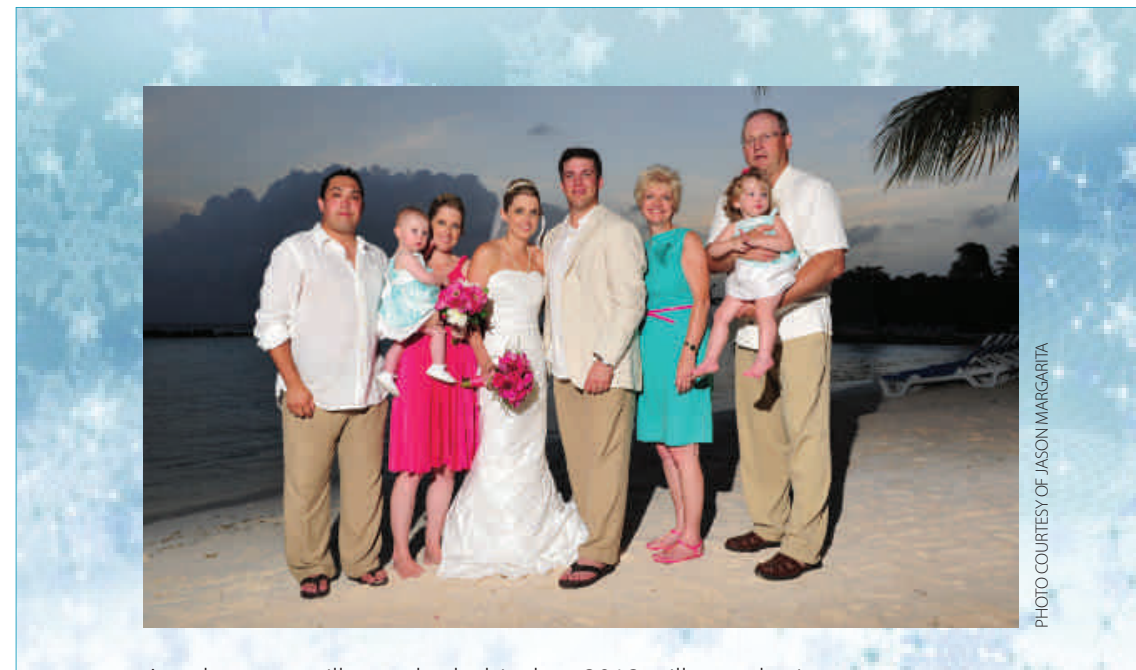

Another year will soon be behind us, 2012 will soon be just a memory time really does fly. My husband Dwight and I will be joining our family in Calgary for the holidays and flying to California on boxing day for some rest and recreation. I encourage all of you to take time to relax, enjoy your family, remember to count your blessings and share with those less fortunate. The Linton family wishes our optometric family across the country health, happiness and prosperity in 2013. I look forward to working with all of you in 2013 as we continue to move the profession of optometry forward.

Une autre année sera bientôt chose du passé, car 2012 ne sera bientôt plus qu'un souvenir - le temps file vraiment. Mon mari Dwight et moi-même allons nous joindre à notre famille à Calgary pour les vacances et nous nous envolerons pour la Californie le lendemain de Noël afin d'y trouver un peu de repos et de détente. Je vous encourage tous à prendre le temps de vous détendre, à profiter de votre famille, à ne pas oublier de compter vos bénédictions et de partager avec les moins fortunés. La famille Linton souhaite à notre famille optométrique d'un bout à l'autre du Canada santé, bonheur et prospérité en 2013. J'ai hâte de collaborer avec vous tous en 2013 pendant que nous continuons de faire avancer la profession.

- Dr. Lil Linton, CAO President/ La Dre Lil Linton, présidente de l'ACO
Providers may call the Customer Service Centre toll-free if they have further questions: 1-800-667-4511 (in Atlantic), 1-800-355-9133 (in Ontario).1-888-588-1212 (in Quebec). Providers in other provinces please contact your local Blue Cross.

\section{Annonce sur la Croix-Bleue}

Le 17 septembre 2012, Croix Bleue Medavie a lancé une nouvelle carte d'identité en plastique à deux côtés, semblable aux cartes bancaires. La nouvelle carte sera fournie aux nouveaux membres de Croix Bleue Medavie, ainsi qu'à tout membre actuel qui doit modifier l'information contenue sur sa carte d'identité actuelle, comme son nom ou son statut de personne à charge. Croix Bleue Medavie met cette nouvelle carte d'identité en service de façon décalée et ne remplacera pas toutes les cartes en vigueur. Beaucoup de membres de Croix Bleue Medavie continueront d'utiliser une carte laminée bleue à quatre côtés. Au Québec, une carte en plastique jaune à deux côtés existe aussi. II faut noter que les membres du programme fédéral (GRC, Anciens Combattants, Forces canadiennes et Citoyenneté et Immigration Canada) n'ont pas de carte Croix Bleue Medavie.

S'ils ont d'autres questions, les fournisseurs peuvent appeler gratuitement le Centre des services à la clientèle : 1-800667-4511 (Atlantique), 1-800-355-9133 (Ontario), 1-888-588-1212 (Québec). Les fournisseurs des autres provinces sont priés de communiquer avec leur Croix Bleue locale.

\section{Eyefoods Book Offer}

Thank your faithful patients, referring doctors, or staff and show them your appreciation with a gift of good health this holiday season. The Eyefoods book makes a fitting present and an acknowledgment of their patronage and support throughout the year. Show your gratitude and take advantage of our special holiday offer: or kick start January's "get healthy" resolutions and sell Eyefoods books in your practice 
for $\$ 24.95$. Click the link to purchase books from the Eyefoods online store. Purchase a box of 36 books for $\$ 13$ a book ( $\$ 468$ plus tax and shipping). That's a combined total of \$1,195 off the retail price! http:// eyefoods.3dcartstores.com/36-BooksEyefoods-A-Food-Plan-for-Healthy-EyesHoliday-Gift-Special_p_23.html

\section{Offre Eyefoods}

Remerciez vos patients fidèles, les médecins qui les réfèrent ou les membres du personnel en leur témoignant votre appréciation par un cadeau de bonne santé au cours de la saison des Fêtes. L'ouvrage Eyefoods constitue un cadeau bien adapté et reconnaît leur clientèle ou leur soutien tout au long de l'année. Montrez-leur votre gratitude et profitez d'une offre spéciale des Fêtes, ou lancez rapidement les résolutions « de bonne santé » de janvier et vendez les ouvrages Eyefoods dans votre cabinet au montant de 24,95 \$. Cliquez sur le lien de l'ouvrage au magasin en ligne d'Eyefoods. Achetez un carton de 36 ouvrages au prix de 13 \$ I'unité (468 \$ plus taxes et frais de port). Ce montant représente au total 1195 \$ de moins que le prix de détail! http://eyefoods.3dcartstores.com/36Books-Eyefoods-A-Food-Plan-for-HealthyEyes-Holiday-Gift-Special_P_23.html

\section{New Canada Not-For-Profit Corporations Act}

On October 17, 2011 the Federal Government enacted the new Not-For-Profit Corporations Act and all federally incorporated not-for-profit organizations have 3 years to transition to the new act. This comprehensive act provides a foundation for the internal management of not-for-profit corporations. The transition process involves a review of the articles of incorporation and by-laws and to adopt changes to comply with the new act. The CAO studied the requirements to transition with the intent of presenting the necessary changes for member adoption at the next business meeting of members in Edmonton in July 2013. The timeline was recognized as very tight. The CAO was originally incorporated under a Special Act of Parliament. Special Act organizations are not required to transition by the October 17, 2014 deadline. Therefore, the CAO will take the time it has available to fully investigate a transition to the new act. CAO Council still expects to recommend several by-law changes at the general business meeting in Edmonton. Further information will be brought forward in the near future.

Nouvelle loi canadienne sur les organisations à but non lucratif

Le 17 octobre 2011, le gouvernement fédéral a adopté la nouvelle Loi canadienne sur les organisations à but non lucratif. Tous les organismes sans but lucratif qui ont une charte fédérale ont trois ans pour s'y conformer. Cette loi détaillée jette les bases de la gestion interne des personnes morales sans but lucratif. Le processus de transition comporte une revue des statuts constitutifs et des règlements et l'adoption de modifications pour devenir conforme à la nouvelle loi. L'ACO a étudié les exigences relatives à la transition afin de soumettre les changements qui s'imposent aux membres pour qu'ils les adoptent au cours de leur prochaine séance de travail qui aura lieu à Edmonton en juillet 2013. Le calendrier est très serré. L'ACO a été constituée à l'origine en vertu d'une loi spéciale du Parlement. Les entités constituées en vertu d'une loi spéciale ne sont pas tenues d'effectuer la transition au plus tard à la date limite, fixée au 17 octobre 2014. L'ACO prendra donc le temps mis à sa disposition pour étudier à fond le virage vers la nouvelle loi. Le Conseil de l'ACO s'attend quand même à recommander plusieurs modifications des règlements au cours de la séance de travail générale à Edmonton. D'autres renseignements vous parviendront sous peu.

\section{Director Announcement}

Waterloo's School of Optometry \& Vision Science is pleased to announce that Professor Paul Murphy, BSc, FCOptom, PhD, FAAO, FBCLA, FEAOO will be the school's next director. Dr. Murphy is an optometrist (Cardiff), with a PhD (Glasgow) in ocular surface sensation and a postgraduate certificate in tertiary level teaching methods. He is currently working toward acquiring his MBA from the University of Glamorgan. He was previously a lecturer in the Department of Vision Sciences (Glasgow) and is currently Reader and Director of Teaching at the School of Optometry and Vision Sciences at Cardiff University. The attached link to the school's web-site provides a brief description of Dr. Murphy's career to date uwaterloo.ca/optometry-vision-science/ news/director-announcement. The school's interim administration will continue its work through to Professor Murphy's arrival.

\section{Nomination d'un directeur} annoncée

L'École d'optométrie et des sciences de la vision de Waterloo est heureuse d'annoncer que le Pr Paul Murphy, BS, FCOptom, PhD, FAAO, FBCLA, FEAOO, sera le prochain directeur de l'École. Le Dr Murphy est optométriste (Cardiff) et titulaire d'un doctorat (Glasgow) en sensation des surfaces oculaires et d'un certificat postdoctoral en méthodes d'enseignement au niveau tertiaire. II prépare actuellement son MBA de I'Université de Glamorgan. Auparavant chargé de cours au Département des sciences de la vision (Glasgow), il est actuellement maître de conférence et directeur de l'enseignement à l'École d'optométrie et des sciences de la vision de l'Université de Cardiff. Le lien ci-joint vers le site Web de l'école donne accès à une brève description de la carrière du Dr Murphy jusqu'à maintenant - uwaterloo.ca/optometry-vision-science/news/ director-announcement. L'administration intérimaire de l'école poursuivra son travail jusqu'à l'arrivée du Pr Murphy. 


\section{$\mathrm{CCOHS}$ Podcast}

Dr. Cheryl Zimmer, Interim Director, Third Party Plans, CAO participated in an interview with the Canadian Centre for Occupational Health and Safety for a podcast about Computer Vision Syndrome. $\mathrm{CCOHS}$ is promoting the podcast through its Health and Safety Report newsletter emailed to 32,000 subscribers and Liaison Report that goes to 11,000 subscribers. It is also being promoted through social media. You may listen to the podcast at this link: ccohs.libsyn.com/shedding-lighton-computer-vision-syndrome.

\section{Balado du CCHST}

La Dre Cheryl Zimmer, directrice intérimaires, Régimes de tiers, ACO, a participé à une entrevue avec le Centre canadien d'hygiène et de sécurité au travail pour un balado portant sur le syndrome de vision informatique. Le CCHST fait la promotion du balado dans son bulletin Rapport sur la santé et la sécurité envoyé par courriel à 32000 abonnés et dans le bulletin Liaison, que reçoivent 11000 abonnés. On en fait aussi la promotion dans les médias sociaux. Vous pouvez écouter le balado en suivant ce lien : ccohs.libsyn.com/shedding-light-on-computer-vision-syndrome.

\section{New Optometry Forum}

an email-based and commercially-independent forum restricted to Canadian optometrists and optometric educators (i.e. professors in a school of optometry). The COG delivers email posted to subscribers by other subscribers. The originators hope this simple resource will be helpful for colleagues across Canada to communicate anything relevant to optometric practice clinical questions, eye-care news, practice management tips, etc. It is a forum for optometrists organized and operated by two Canadian optometrists, Peter Rozanec, OD \& Glen Chiasson, OD. If you are interested in becoming a member, please let them know and spread the word. To join, send an email to: canadianoptometrygroup@ gmail.com.

\section{Nouveau Forum de}

\section{l'optométrie}

Le Canadian Optometry Group (COG) est un forum électronique et indépendant sur le plan commercial qui est réservé aux optométristes et aux éducateurs en optométrie du Canada (c.-à-d. aux professeurs des écoles d'optométrie). Le COG livre des messages électroniques aux abonnés affichés par d'autres abonnés. Les auteurs espèrent que cette ressource simple aidera des collègues de partout au Canada à diffuser tout ce qui est important pour la pratique de l'optométrie - questions cliniques, nouvelles sur les soins oculovisuels, conseils sur la gestion d'un cabinet, etc. Ce forum qui s'adresse aux optométristes est organisé et administré par deux optométristes canadiens, Peter Rozanec, OD, et Glen Chiasson, OD. Si vous souhaitez devenir membre, veuillez les en informer et faire passer le mot. Pour adhérer, envoyez un message électronique à : canadianoptometrygroup@gmail.com.

\section{Website Updates}

Recent website changes of note include the CAO history page, which now includes a copy of the wording of the Federal Act to Incorporate the Canadian Association of Optometrists, a gallery of CAO presidents, and dates/locations of CAO Congresses. Information about Occupational Vision Care programs has been moved from the Open your eyes micro site to opto.ca/ovp. This page includes links to provincial OVC/OVPs and tips for completing forms. For those members who participate in the Ontario OVP, there is also additional content found when clicking on the 'Ontario' link.

\section{Incident Reporting}

CAO reminds members to report patient incidents on the national incident reporting site. Add to your provincial total by reporting asymptomatic patients, invalid prescriptions, online ordering, sight tests, and cosmetic contact lenses.

Please support this effort! To report an incident, visit: www.surveymonkey.com/s/ODincidentreport

\section{Déclaration des incidents}

L'ACO rappelle aux membres de déclarer les incidents liés à des patients sur le site national de déclaration des incidents. Contribuez aux totaux de votre province en déclarant les patients asymptomatiques, les prescriptions non valides, les commandes en ligne, les tests de la vue et les lentilles cornéennes à but esthétique.

Veuillez appuyer cet effort! Pour signaler un incident, rendez-vous à : http://www.surveymonkey.com/s/ ODrapportincident

Mises à jour de site Web

Des modifications récentes et dignes de mention du site Web comprennent la page sur l'histoire de l'ACO, qui inclut maintenant une copie du texte de la Loi fédérale constitutive de l'Association canadienne des optométristes, une galerie de portraits des présidents de l'ACO et les dates et lieux des congrès de l'ACO. L'information sur les programmes de soins professionnels de la vue a été transférée du microsite Ouvrez les yeux à opto.ca/ rpv. Cette page comprend des liens vers les SPV/RPSV des provinces, ainsi que des conseils sur la façon de remplir les formulaires. Les membres qui participent au programme RPSV de I'Ontario y trouveront du contenu supplémentaire en cliquant sur le lien «Ontario ». 